some 400,000 references will be fed into the system each year, of which 75,000 will be to new compounds, and the system will identify any compound which has previously been processed and assign the same number to it each time it appears. The Federal Council for Science and Technology has made a task group of its Committee on Scientific and Technical Information responsible for developing a long-range plan for improving national scientific and technical information systems. The Atomic Energy Commission and the National Bureau of Standards are jointly sponsoring an Atomic and Molecular Processes Information Centre at the Oak Ridge National Laboratory to collect, store, evaluate and disseminate information from all over the world relating to atomic and molecular cross-section and other particle collision processes in the three areas: interaction of heavy particles; particle penetration through matter; excitation, dissociation, ionization and detachment by external electric and magnetic fields.

\section{The Royal Ontario Museum, University of Toronto}

THE annual report of the Royal Ontario Museum for the year July 1963-June 1964 is of special interest in that it records the reorganization that has been undertaken by the new director, Prof. W. E. Swinton, late of the British Museum (Natural History) (Pp. 16. Toronto: Royal Ontario Museum-University of Toronto, 1965). In brief, the director now takes a larger place in the University, becoming a member of the Senate, and of the Council of the Faculty of Arts and Sciences. In the Museum he is responsible for general policy, curatorial matters, display and academic publication. The Associate Director is responsible for the non-curatorial staff, and for day-to-day administration. The abolition of the divisional structure gives a large measure of autonomy with, of course, increased responsibility to each of the departments. All curators have direct access to the Director, and each has inaugurated research programmes of a high order. This new upsurge of activity has already borne fruit in the form of publications completed during the year and now in the press. In several cases some of this work has been done jointly with other institutions, for example, with McGill University in ichthyological researches in Barbados, and with the National Museum of Canada in an anthropological project.

\section{The Museums and Art Gallery, Leicester}

THe fifty-eighth report of the Committee of the City of Leicester Museums and Art Galleries, for 1963-64, records that much thought has been given to the establishment of a museum of science and technology (Pp. 13. Leicester: The Museums and Art Gallery, 1965). The popular interest shown in industrial archaoology indicates that this is a growing study, the importance of which should be reflected in the Museums. However, material is being collected and this eventually will form the nucleus of the collections. The new Museum of Archaeology on the Jewry Wall has been completed and the Committee has plans to tidy up the Newarke Groteway. An interesting appointment was that of Mr. G. J. Bemrose, late director at Stoke-on-Trent Museums, to advise on the purchase of ceramics-a branch of applied art in which the Museum's collections were curiously deficient. Although the Committee is continuing to train student-assistants and appoint trainee-assistants, there is still a dearth of officers for the more senior posts, and most of the departments of the Museum are understaffed. The report is well illustrated, has an arresting cover, and concludes with an impressive list of acquisitions.

\section{Atlas of the Antarctic}

THE weekly journal of the Russian book trade, Novye Knigi, announces the forthcoming appearance, late in 1965, of a major Atlas of the Antarctic, to be published by the Main Administration for Geology and Cartography (GUGK) of the U.S.S.R. The work will incorporate the results of the cartographical, geological and geophysical researches of the twelve nations which have collaborated in Antarctic work during and since the International Geophysical Year. It is planned in two volumes, the first of which (Pp. 300 , size $38 \times 60 \mathrm{~cm}$., price 30 roubles) will comprise maps of all kind, and the second (price 5 roubles) an explanatory text. Orders placed through the national agencies for Russian books should quote Novye Knigi 25-1965, item 21.

\section{Scottish Field Studies}

THE Scottish Field Studies Association opened its Field Studies Centre at Kindrogan, Perthshire, in November 1963 , and, in its annual report for 1964, reviews the Centre's activities to date (Pp. $25+4$ plates. Glasgow: The Scottish Field Studies Association, 1965. 5s.). During the first season, 502 students attended, 134 taking courses in geography, 72 in biology, 175 in botany and 121 in a combined course of biology and geography. 214 of the students came from schools, 110 from universities and technical colleges, 54 from training colleges and 124 paid 'unattached' visits. With its attractive facilities, Kin. drogan should gain increasing support; however, although it has received generous financial support from educational bodies, the complete lack of response to an appeal from Kindrogan to Scottish industry is not only lamentable but shows how short-sighted industrialists can sometimes be.

\section{Comparison of Colorimeters}

THE Association of Clinical Biochemists has published Scientific Report No. 1, entitled Colorimeters Fitted with Flow Through Cells (Pp. 54. Liverpool: J. T. Ireland, Biochemistry Laboratory, Alder Hey Children's Hospita], 1965. 13s. 6d.; Association members, 8s. 6d.). In these instruments, the optical densities of a number of solutions, for example a batch of blood haemoglobin solutions, can be measured without removing the optical cells from their holders. The report gives a detailed and critical appraisal of four commercial colorimeters of this type. All four contained a selenium photocell and the wave-length band was selected by use of colour filters or an interference wedge. The report also covers such topics as maintenance, faults developing during use and the adequacy of the instruction booklets. The methods developed for assessing the performance of the instruments should be helpful to anyone wishing to test the performance of any colorimeter. The report should also be helpful to manufacturers anxious to improve the design and reliability of their instruments.

\section{Progress in Concrete Research}

As forecast in the previous report for 1963 (Nature, 204,233 ; 1964), the Hon. Leo Russell, director-general of the Cement and Concrete Association, in his introduction to the report for 1964 confirms that the increase in the financial resources of the Association has been reflected in each of its main fields of activity during that year (Pp. 116. London: Cement and Concrete Association, 1965). In research and development projects, special mention is made of the work on factors affecting skidding resistance of concrete roads at high speed, carried out in close collaboration with the Road Research Laboratory; on investigations of surface appearance of in situ concrete, culminating in the symposium organized jointly with the Royal Institute of British Architects in October 1964; and on the introduction of 'Standard Mixes' by the committees responsible for the preparation of the new Code of Practice for Precast Concrete $(C P$ 116) and for amendments to the Code of Practice for Reinforced Concrete (CP 114). Further developments in the matter of standard prestressed precast concrete beams for bridges are also 